\title{
沖縄県における銀行および航空会社勤務健康成人の 骨密度に関する研究
}

鈴木 信* 安次富郁哉** 秋坂 真史*John Max Vogel ${ }^{* * *}$

\section{Bone Mineral Density of Healthy Bank Clarks and Employees of an Air Line Company in Okinawa}

\section{Makoto SUZUKI*, Ikuya ASHITOMI**, Masafumi AKISAKA* and John MAX VOGEL***}

In order to gain predictive information for prevention of osteoporosis and fracture in healthy adults, Calcaneal BMD (Bone Mineral Density) levels were measured by using an osteoanalyzer, model SXA 2000 system produced by Dove Medical Co. in USA, by means of single energy X-ray absorptometry. The subjects, all healthy, consisted of 153 bank clarks and 51 employees of an airline company in Okinawa. A gradual decreasing tendency of mean BMD observed from twenty years of age in both males and females and the 50-59 years of age group, showed significantly lower levels than the 40-49 years of age group in females. Female levels were lower than male levels in every 10 year group from 20 to 50 years of age.

In the airline company, the average BMD level of air hostesses was the lowest compared to manager groups and business staffs. According to statistical analysis, $p$ values were not significant in the student $t$ test, because subject size was too small.

In comparison with standard levels of BMD in healthy adults between Okinawa and Fukushima for females and between Okinawa and Tottori for males, the following tendencies were observed: Okinawa levels were higher than both Fukushima and Tottori for females over 40 years of age and for males over 50 years of age.

Key words : bone mineral density, single energy X-ray, osteoabsorptometry, Okinawa, healthy, employee of air line company.

骨密度，SXA，沖縄，航空会社勤務員

* 琉球大学医学部附属地域医療研究センター

** 琉球大学医学部附属病院地域医療部

*** School of Medicine University of California, Davis, USA

* Research Center of Comprehensive Medicine, University of the Ryukyus

** Department of Community Medical Service, University of the Ryukyus Hospital

*** School of Medicine University of California, Davis, USA 


\section{I 緒言}

日本，欧米諸国では高齢化社会が進行するにつ れ，寝たきりや痴呆性老人が急増して医療福祉の 問題だけではなく，大きな社会問題にすらなって いる。

これらの disabilityを生ずる大きな原因の一つ に骨粗鬆症がある，骨粗箖の程度を予知するため には，個人の骨密度を知って，個別に戦略を立て ることが，プライマリーケアーを展開する上に必 要なことである，そこで，沖縄県の 30 歳〜 50 歳の 産業勤務者を対象に SXA 法によって骨密度を測 定して，disabilityへのリスク削減戦略を立てる ために職業との関連性を考察したので報告する.

\section{II 対 象}

沖縄県内の $\mathrm{K}$ 銀行の行員20～50歳の153人（男 57 人，女 96 人）と某航空会社の女性 $20 \sim 40$ 歳の 51 人である．彼らの性別年齢別内訳は表 1 に示すと おりである。銀行従業員は事務と営業であるが,

表1-1 K銀行および J 航空会社被験者数

\begin{tabular}{|c|c|c|c|c|c|}
\hline 性別 & 男 & & & 女 & \\
\hline 年代 & K銀行 & & $\mathrm{K}$ 銀行 & $\mathrm{J}$ 航空会社 & 合計 \\
\hline 20歳代 & 7 & 41 & 23 & 18 & 48 \\
\hline 30歳代 & 13 & 52 & 32 & 20 & 65 \\
\hline 40歳代 & 19 & 45 & 32 & 13 & 64 \\
\hline 50歳代以上 & 18 & 9 & 9 & - & 27 \\
\hline 合計 & 57 & 147 & 96 & 51 & 204 \\
\hline
\end{tabular}

表1-2 J 航空会社の職域別被験者数（女性）

\begin{tabular}{|c|c|c|c|c|}
\hline 年代 & 機上職 & 事務職 & 営業職 & 合計 \\
\hline 20 歳代 & 2 & 14 & 2 & 18 \\
\hline 30 歳代 & 0 & 14 & 6 & 20 \\
\hline 40 歳代 & 3 & 7 & 3 & 13 \\
\hline 合計 & 5 & 35 & 11 & 51 \\
\hline
\end{tabular}

専門職としての区別が困難であるが，一方航空会 社の場合は，事務，営業系と機上職の区別が歴然 としている.

いずれも，企業の健康管理担当者に調査への協 力方を要請し，十分説明をした上，同意・了解を 得た者のみを骨密度測定の対象とした。測定施行 時に，彼らに，顕性の疾病罹患は無かったので， 本研究には健康ボランティアを対象にしたことに なる。

\section{III 方 法}

骨密度の定量は米国タブメディカル社製の SXA2000システムを用い, Single energy X ray absorptometry 法で行った。レントゲン室内に通 常の椅子とその前にスキャナーのある足置き台を 設置する，スキャナーの中央に足を型どったヒー ルチュウブがあり，測定の都度ヒールチュウブ内 に新しい蒸留水を満たす。まず被験者を椅子に座 らせ，右または左の腫骨部を足の形に合わせて ヒールチュウブ内に入れる。次いで，腫骨部の X 線のスキャンを開始するとともに，計測プログラ ムにそって腫骨の BMD (bone mineral density) を測定する。この際の被曝量は僅少で， $2 \mathrm{~cm}$ の障 壁部透過後で $42 \mu / \mathrm{SV}$ で 1 回の胸部 X 線撮影の 100 分の 1 程度である.また測定に要する時間は平 均 $3 \sim 4$ 分である.データのプリントアウトは後 刻まとめて行った。

統計解析はグループ間比較には $\mathrm{t}$ 検定を，年齢 傾向比較にはANOVA 検定を行い，危険率 $5 \%$ をもって有意性の判定とした。

\section{IV 成 績}

職業毎に男女別，ならびに年齢階層別 BMD の 平均值と標準偏差值は図 1 ～ 2 に示すとおりであ る．全年齢層にわたって，女性より男性のほうが $\mathrm{t}$ 検定により，明らかに骨密度が高かった。年齢階 層別に検討したところ，男女共に年齢と共に減少 傾向がみられるが，40歳までは有意差は認められ なかった。女性では50歳で40歳以下に比して急速 に低下がみられ，20歳代との間に有意差が認めら 


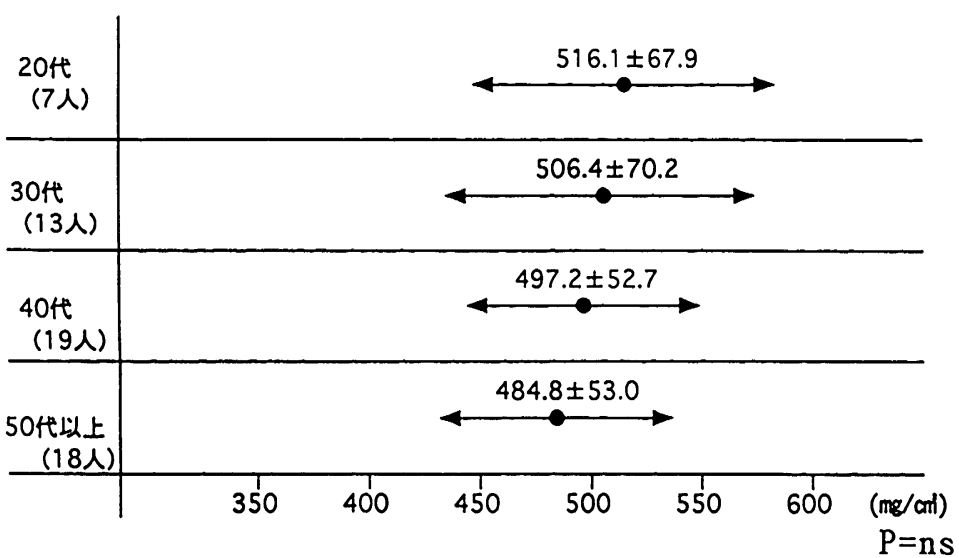

図 1 年歯階層別骨密度 (平均值土標準偏差)

（男性）K 銀行

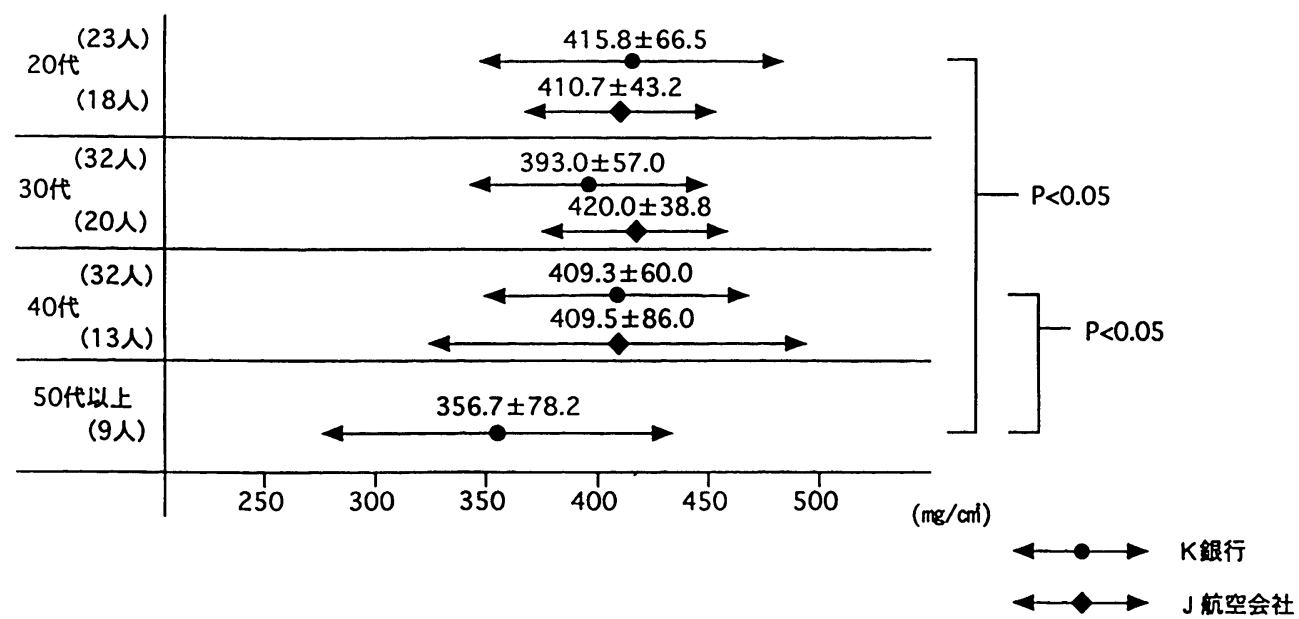

図 2 年歯階層別骨密度 (平均値士標準偏差)

（女性） $\mathrm{K}$ 銀行・J 航空会社

れた。

銀行貣では男女共に, 事務的労作が主体で, 業 種別な分類はできなかったので業種比較を行って いない, むしろ女性が営業で, 男性が事務系の業 務に就いていることが多い. 航空会社では機上の 機上職と地上の営業職と事務職の 3 種に分けて比 較した成績は, 図 3 に示すと抢りである。その結 果, 機上，事務，営業の順に骨密度が高くなって いるが，いずれのグループでも有意差が認められ なかったが, 例数を十分取ることによって機上職
が営業職より，低い值となることが推考される。 本機種を用いた本法による健康成人值は，月川ら （1993）および片桐ら（1993b）のデータしか発表 されていないのでそれらを利用することにした。 月川らは女性について，片桐らは男性についての みのデータであるが, 性別, 年齢別の基準值をも とに1.5SD 以上の低下を示す症例と\%は表 $5 ， 6$ に示すとおりである，それらを基に我々の測定結 果を検討して, 表 $2 ， 3$ に示した。 その結果, 異 常者は $\mathrm{K}$ 銀行では男 2 人 ( $4 \%)$ ，女 10 人 ( $10 \%)$ ， 


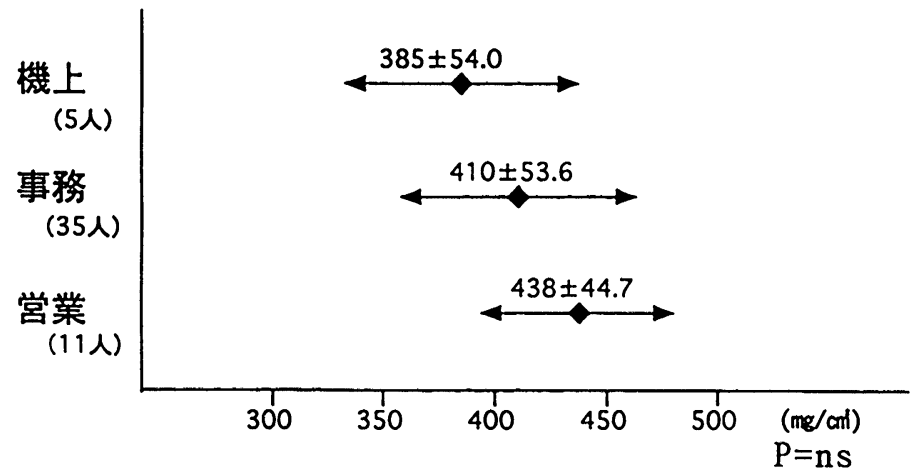

図 3 職域別骨密度 (平均値士標準偏差)

(J 航空会社)

表 2 年代別骨密度測定結果 - 男性

\begin{tabular}{c|ccc}
\hline 年代 & 人数 & 正常 & 異常 \\
\hline 20 歳 代 & 7 & $6(86)$ & $1(14)$ \\
\hline 30 歳 代 & 13 & $12(92)$ & $1(8)$ \\
\hline 40 歳 代 & 19 & $19(100)$ & 0 \\
\hline 50 歳代以上 & 18 & $18(100)$ & 0 \\
\hline 合計 & 57 & $55(96)$ & $2(4)$ \\
\hline
\end{tabular}

$\mathrm{J}$ 航空会社では女 7 人 (14\%) であった。 J 航空会 社の職種別検討では表 4 に示すとおり, 異常者は 機上職が 1 人 $(20 \%)$, 事務職が 4 人 (11.4\%), 営業職が 2 人 $(18.2 \%)$ であった。

\section{$\mathrm{V}$ 考察}

日本人の長寿には殊に定評があって, 年々その 記録を更新している.1990年では平均余命が男性 で76.04歳, 女性は82.07歳になった。しかも, 沖

表 3 年代別骨密度測定結果 女性

\begin{tabular}{|c|c|c|c|c|c|c|}
\hline \multirow[b]{2}{*}{ 年代 } & \multicolumn{2}{|c|}{ 人 数 } & \multicolumn{2}{|c|}{ 正 常 } & \multicolumn{2}{|c|}{ 異 常 } \\
\hline & $\mathrm{K}$ 銀行 & $\mathrm{J}$ 航空会社 & K銀行 & $\mathrm{J}$ 航空会社 & K銀行 & J 航空会社 \\
\hline 20 歳代 & 23 & 18 & $19(83)$ & $15(83)$ & $4(17)$ & $3(17)$ \\
\hline 30 歳 代 & 32 & 20 & $26(81)$ & $20(100)$ & $6(19)$ & 0 \\
\hline 40 歳代 & 32 & 13 & $32(100)$ & $9(70)$ & 0 & $4(30)$ \\
\hline 50歳代以上 & 9 & 0 & $9(100)$ & 0 & 0 & 0 \\
\hline 合計 & 96 & 51 & $86(90)$ & $44(86)$ & $10(10)$ & $7(14)$ \\
\hline
\end{tabular}

表 4 職種別骨密度異常者数(率)

\begin{tabular}{cccc}
\hline 職種 & 人数 & \multicolumn{1}{c}{ 正常 } & 異常 (1SD 以下) \\
\hline 機上職 & 5 & $4(80.0)$ & $1(20)$ \\
\hline 事務職 & 35 & $31(88.6)$ & $4(11.4)$ \\
\hline 営業職 & 11 & $9(81.8)$ & $2(18.2)$ \\
\hline 合計 & 51 & $44(86.0)$ & $7(14)$ \\
\hline & & & $\mathrm{J}$ 航空会社
\end{tabular}

縄はその中でも日本一の記録であって,女性 84.47 歳, 男性76.67歳である.1996年には「長寿のあし あと」に発表しているように，沖縄が世界一長命 地域であることを宣言した。しかし，厚生省およ び沖縄県生活福祉部の発表によると, 沖縄は本土 に比して墁たきりや痴呆性老人数が多い. 概して, disability は高齢の度合いが高くなればなる程, 
表 5 福島県と沖縄県の骨密度(平均值士標準偏差・女性)

\begin{tabular}{|c|c|c|c|c|c|c|c|c|}
\hline  & $20 \sim 24$ & $25 \sim 29$ & $30 \sim 34$ & $35 \sim 39$ & $40 \sim 44$ & $45 \sim 49$ & 5()$\sim 54$ & $55 \sim$ \\
\hline 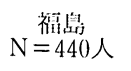 & $\begin{array}{l}435 \\
\pm 67\end{array}$ & $\begin{array}{l}434 \\
\pm 61\end{array}$ & $\begin{array}{l}412 \\
\pm 7\end{array}$ & $\begin{array}{l}398 \\
\pm 54\end{array}$ & $\begin{array}{l}398 \\
\pm 53\end{array}$ & $\begin{array}{l}380 \\
\pm 53\end{array}$ & $\begin{array}{l}315 \\
\pm 62\end{array}$ & $\begin{array}{l}315 \\
\pm 46\end{array}$ \\
\hline $\begin{array}{c}\stackrel{\text { 汒䋲 }}{N=147 人}\end{array}$ & \multicolumn{2}{|c|}{$414 \pm 58$} & \multicolumn{2}{|c|}{$403 \pm 53$} & \multicolumn{2}{|c|}{$490 \pm 67$} & \multicolumn{2}{|c|}{$357 \pm 83$} \\
\hline
\end{tabular}

$\left(\mathrm{mg} / \mathrm{cm}^{2}\right)$

表 6 福島临と沖縄県の骨密度 (平均値士標準偏差・男性)

\begin{tabular}{ccccc}
\hline 年榆(藏) & $20 \sim 29$ & $30 \sim 39$ & $40 \sim 49$ & $50 \sim$ \\
\hline $\begin{array}{c}\text { 岕取 } \\
\mathrm{N}=258 \text { 人 }\end{array}$ & $541 \pm 77$ & $503 \pm 82$ & $497 \pm 81$ & $477 \pm 85$ \\
\hline $\begin{array}{c}\text { 沖縄 } \\
\mathrm{N}=57 \text { 人 }\end{array}$ & $516 \pm 73$ & $506 \pm 73$ & $497 \pm 54$ & $485 \pm 55$ \\
\hline
\end{tabular}

$\left(\mathrm{mg} / \mathrm{cm}^{2}\right)$

また，女性の比率が高くなればなる程多くなるこ とを，1996年「沖縄高龄者実態調查報告」に報告 したそそれに，高秢者の中でも，超高龄者人口の 多いことに由来することを証明した，WHOの中 嶋総長は「長寿のあしあと」(1995) に記載されて いるように，「単なる長命ではなく，寝たきりや痴 呆でない活動性の高い老人の平均余命が高い地域 を以って長寿地域とする」とのべている.

男性の disability は脳血管障害によるものが多 いが，女性では大半が骨粗箖症が原因で，大腿骨 骨折や脊椎骨折を起こし寝たきりになり，さらに 倁呆へと進展する。

骨密度の測定は骨粗政症の補助診断になるし， 重症度判定には欠かせない。しかも，1988年， Vogel らは骨粗秐症ないし，それによる骨折の予 知が可能と述べている. Washich ら (1978・1985), Ross ら (1987) は，それを，骨折をターゲットと した $\mathrm{BMC}^{\sharp !} 0$ の prospectiveな分析によって証明 している. Vogel ら (1988)によると，女性グルー プにて腫骨の低 BMC グループが高 BMC グルー プの10.7倍の骨折を年間に記録している。それは， Kagan ら（1985）による八ワイの日系人について の調査による高血圧の脳卒中発症率の 8 倍を凌駕 しているので，低 BMC は骨折の大きなリスク ファクターであると言える。
測定部位として全身，大腿骨，脊椎，橈骨，腫 骨などがあるが，腫骨が海綿骨を $95 \%$ も含んでい ること，周囲に軟部組織が少ないことなどによっ て，腫骨の BMC が全身の骨密度を反映する度合 いが高く，游ら（1993）は殊に大腿骨の骨密度と の相関が高いと報告している。

Kin ら (1991) は，腰椎の骨密度測定の場合は周 囲組織による補正が必要であり，そのため，DXA として 2 方向測定を锥めている．片桐ら（1993a） は，脊椎の DXA 法では正面方向は高い再現性が 証明されているが，側面方向では問題性が指摘さ れている。また，高齢になると変形性脊惟症によ る骨周辺組織へのカルシウム沈着や脊椎の近位に ある大動脈へのカルシウム沈着によって，測定值 が実際の脊椎海綿骨の骨密度よりも高くでてくる 可能性がある，その意味で腫骨の測定のほうが有 用と思われる。さらに, DXA 法は, 機器のスペー ス, 機器の大きさ, 被曝量, コストの面で不利で ある。一方，游ら（1993）は，腫骨の場合は一方 向の SXA が可能であるばかりではなく，測定方 向や部位を一定にさせやすいので，再現率が高い と述べている。彼らは再現性0.68 と報告し，片桐 ら（1993a）は日内変動0.97, 日差変動0.98と発表 している，従って，時間を追って記録することに よって経過観察をしたり，ライフスタイルの介入 や治療効果判定にも有用であり，かつ測定時間が 短く, 操作が簡単なためスクリーニングにも適し ているとする鈴木ら（1993）に同感である.

男女間の比較は $\mathrm{K}$ 銀行でみられるように，いず れの年噛層においても男性のほうが明らかに高 い。これは月川ら（1993）による標準值データー に一致している。J 航空会社女性群について職種 別にみたところ，機上職が最も低く，次いで事務 
職, 営業職の順となっている. 事務職と営業職は 勤務交代によって移動があるため, 判然とした職 種区別はつかないが, 機上職は勤務が固定されて いて, 同一職種内のシフト勤務となっている. 本 調査では対象例数が高くなかったので, 他職種と の有意差を認めることができなかった。しかし， 故意に選出したグループではなかったので, 機上 職のほうが BMD が低い可能性は高い。機上職は, 職種上採用時点から特定の体格の人が好まれて選 出されている可能性もあって, BMD が元々低 かったのかも知れない. しかし, 彼女らは生活が 不規則であり，運動習慣が必ずしも高くないと考 えられる。従って職種間の比較には, 一概に労働 条件や勤務状況の良悪を論ずることはできない. そのためには，ライフスタイルや食習慣を含めて 一層の詳しい調査が必要と思われる。

男女ともに, 年齢が進むにつれて, 徐々に骨密 度の低下がみられる。既に，30歳から低下傾向が みられるのは, SXA による腫骨の骨密度を測った 游ら (1993)の発表に一致している.しかも, 40〜50 歳代で大幅に低下していて, 閉経期以後に急速に 低下傾向にあるのもWashich ら（1978）の発表に 一致している.

BMD の標準值にも，人種差や地域差がみられ る. Vogelらによると, 白人, 黒人, 東洋人の順 位であり，台湾は日本より高い.日本国内では必 ずしも県民を代表することにはならないが, 表 5 , 6 に示しているように，月川ら（1993）の女性の 福島のデータや，片桐ら (1993b) の男性の鳥取の デー夕と我々の沖縄県健康勤務者を比較した発表 によると, 女性は 20 歳では福島のほうが高く, 加 齢と共に我々の調査群では高くなり，40歳では逆 転し年齢と共に差が一層大きくなってくる.また， 男性では，20歳では鳥取が高く30歳では逆転し， 我々の調查群で高くなり，50歳では一層差がつい ている.つまり, 我々の調査群では成人以後, 男 女共に高くなっている.Vogel らは沖縄の高齢者

註) BMC (Bone Mineral Contents) 骨塩量： $\mathrm{BMD}$ 骨密度とは用語の定義上異なるが，ほぼ同 義語に使用されている。
に関しても，研究して高い BMD を記録している が, 次回発表の予定である.

沖縄県の寝たきり率は日本本土より高いが, こ れは, 年齢層の違いの因子が大きく, 沖縄は全国 の老人に比して超高齢者が多いのであって, 年齢 をマッチさせて求めれば寝たきりはむしろ, 沖縄 のほうが低くなっていると思われる。秋坂ら （1993）によると，超音波法によって測定した BMD であるが，沖縄の高齢者の BMD が高いと 報告している．これらの背景因子として沖縄独特 のライフスタイルが考えられるので, 高齢者に関 してはさらに一層の研究が必要と考えられる。

\section{VI 結論}

健康成人の骨粗鬆症による骨折を予知し予防す るために, 米国ダブメディカル社製 SXA2000シス テムのオステオアナライザーを用いて, 沖縄の某 銀行行員 153 人と某航空会社社員 51 人の腫骨の骨 密度を測定した。

骨密度は, 男女ともに20代より年齢と共に低下 したが，女性では50歳代で，40歳代より著明に低 下が見られた。全年齢層にわたって，女性のほう が男性より低かった。

航空会社では，女性に関して職域別に検討した ところ，母集団が少ないため有意差があるとは認 められなかったが, 機上職が地上職の経理, 営業 担当よりも低い傾向にあった。

健康人の地域別比較をみると, 女性では沖縄の 銀行員㧍よび航空会社勤務員は福島県より40歳代 で高い傾向が, 男性では鳥取県より50歳代で高い 傾向が認められた。

謝辞: 本研究遂行は, 1995年度厚生科学研究費補助 金によった，さらに，研究遂行にあたり多大な御協力 を頂きました方々に深謝申し上げます。

\section{文献}

Akisaka, M., Asato, L., Suzuki, M., Iwamasa, T. \& Yamamoto, S. (1996): Relationship between bone density and nutrient intakes of okinawan centenarians, Osteoporosis Japan, 4(3), 503-509 Kagan, A., Popper, J.S., Rhoads, G.G. \& Yano, K. 
(1985): Dietary and other risk factors in Hawaiian Japanese men, Stroke, 16, 390-396

片桐浩史, 山本吉蔵, 岸本英彰, 荻野 浩, 津田公子 (1993a)：Osteo Analyzer を用いた腫骨骨塩定量， Osteoporosis Japan, 1, 53-57

片梠浩史, 山本吉藏, 岸本英彰, 荻野 浩 (1993b)： SXA 法による腫骨骨高測定と DIP 法との比較, 第 13回日本骨形態形測学会

Kin, K, Kushida, K., Yamazaki, K., Okamoto, S. \& Inoue, T. (1991): Bone mineral density of the spine in normal Japanese subjects using DualEnergy X-Ray absorptiometry : Effect of obesity and menopausal status, Calcif. Tissue. Int, 49, 101 $-106$

高齢者実態調查報告（1996）：沖縄県生活福祉部編， 沖縄総合研究所 (沖縄) 1-175

長寿のあしあと，沖縄県長寿り検証記録（1996）：沖 縄紧環境保健部編，若夏社(沖縄)

Ross, P.D., Washich, R.D., Heilbrun, L.K. \& Vogel, J.M. (1987): Definition of a spine fracture threshold bsed upon prospective fracture risk, Bone, 8, 271-278

鈴木隆雄, 柴田 博, 守木久和 (1994)：DXA 法によ る骨密度集団健㡣での測定精度に関する研究, 日本 公咅誌, 41(10), 997-1005
鈴水雅丈, 畑中三成, 松本洋子, 坂井芳夫 (1993)：枚 方保健所における骨粗鬆㹥予防, 公衆衛生誌, 57(10), $467-471$

月川 奏, 大和田真人, 五十嵐久美子, 他 (1993)：加 齢及び治療に対する骨密度の変化(腫骨一SXA 法 腰椎一DXA 法)ならびに骨萎縮度分類の評価，第13 回日本骨形態形測学会

Vogel, J.M., Washich, R.D. \& Ross, P.D. (1988) : The clinical relevance of calcaneus bone mineral measurement: A review, Bone and Mineral, 5, 35 $-58$

Washich, R.D., Ross, P.D., Heilbrun, L.K. \& Vogel, J.M. (1985) : Prediction of post menopausal fracture risk with use of bone mineral measurements, Am. J. Obstet. Gynecol, 153, 745-751

Washich, R.D., Ross, P.D., Heilbrun, L.K., Vogel, J. M. \& Yano, K. (1978): Selection of the optimal site for fracture risk prediction, Clin. Ortho. Rel. Res, 216, 262-269

游 逸明, 山本逸雄, 大中恭夫, 他 (1993)： SXA (Single Energy X-ray Absorptometry)法による腫 骨骨密度測定の臨床的有用性についての検討, 日骨 形態誌，3，127-131

（受稿 1996.11.13；受理 1997.2.26） 